\title{
The Effect of Varieties and Plant Population Densities on Dry Matter Production, Radiation Interception, and Radiation Energy Conversion in Peanut
}

\author{
Agus Suprapto $^{1 *}$, Yogi Sugito², S.M. Sitompul ${ }^{2}$ and Sudaryono ${ }^{3}$ \\ ${ }^{1}$ Agrotechnology Department, Faculty of Agriculture, Tidar University, Magelang, Center Java, Indonesia \\ ${ }^{2}$ Agroecotechnology Department, Faculty of Agriculture, University of Brawijaya, Malang, East Java, Indonesia \\ ${ }^{3}$ Indonesian Legume and Tuber Crops Research Institute, Malang, East Java, Indonesia
}

\section{ABSTRACT}

The solar radiation is one of the major criteria to obtaining advantages on peanuts (Arachishypogaea L.). Although various combinations of crops have been reported, but variety association and plant population densities (PPD) during the periodically stage of growth on peanuts have yet to be analyzed. Dry matter production (DM), radiation energy interception, and radiation energy conversions were monitored over the growth period of two varieties of peanut. An experiment was conducted in Jambegede Research Farm, Indonesian Legume and Tuber Crops Research Institute, Malang, East Java, Indonesia, from July until October 2011. The experiment was arranged in a Split Plot Design with three replications. Peanut varieties, as the main plot consisted of two treatments: Kelinci and Kancil variety. In addition, five PPD variations as sub plot consisted of 8.1, 11.1, 16.0, 25.0 and 44.4 plant $\mathrm{m}^{-2}$ were arranged in a square spacing. The results showed that DM production from high PPD increased gradually to lower PPD in all varieties. Interception efficiency (IE) increased in all varieties from early sowing. A plant population density of $25.0 \mathrm{~m}^{-2}$ and 44.4 plants $\mathrm{m}^{-2}$ intercepted more radiation over 11.1 or 16.0 plants $\mathrm{m}^{-2}$. Conversion efficiency of radiation energy (CE) to total dry matter production on Kelinci variety $(1.52 \%)$ indicated a slight higher percentage than on Kancil variety $(1.41 \%)$. Moreover, the $\mathrm{CE}$ and IE values indicated a decrease as the PPD increased on maximum DM.

Keywords: interception, peanut, population density, conversion efficiency

\section{BACKGROUND}

Solar energy constitutes a main factor in the growth process of any plants. Solar energy is important as the plants use it to form biomass through photosynthesis process. Counting of growth energy accepted by the leaf surface and resulting in dry weight of plant, the conversion efficiency of the radiation energy is about $2 \%$ [1]. The efficiency is also different among plants and among varieties of plants [2][3].

Conversion efficiency can become a tool for us to understand plants and biomass results, because biomass results of plants have a direct relationship with competence utilize the solar energy to become biomass. Conversion efficiency of solar energy becomes ratio among

\section{*Corresponding address:}

Agus Suprapto

Agrotechnology Department, Agriculture

Faculty, Tidar University, Magelang, 56116, Indonesia.

E-mail: suprapto_suga@yahoo.com solar energy amount that is converted becomes biomass[4]. Since solar radiation did not change, conversion efficiency is equal with plant ability to convert available energy as biomass [5]. The low conversion efficiency also was due to reflection of solar energy that falls at plant canopy, transpiration and respiration [6]. Therefore this experiment had analyzed the dry Matter production, radiation interception and conversion efficiency of radiation energy in varieties and plant population densities on Peanut.

\section{MATERIAL AND METHODS}

An experiment was carried out from July until October 2011 at Jambegede Research Farm, Indonesian Legume and Tuber Crops Research Institute, Malang. Material that was utilized on this study was Kelinci and Kancil varieties of peanut. Phonska fertilizer $300 \mathrm{~kg} \cdot \mathrm{ha}^{-1}$ and SP 36 $100 \mathrm{~kg} \cdot \mathrm{ha}^{-1}$. The experiment was conducted on a 
split-plot design that was arranged in a block random design in three replications. Varieties as main plot consisted of two treatment, they are Kelinci (V1) and Kancil (V2). Five population densities variation as sub plot consisted in square spacing of $15 \times 15 \mathrm{~cm}$ (J1), $20 \times 20 \mathrm{~cm}$ (J2), $25 \times$ $25 \mathrm{~cm}$ (J3), $30 \times 30 \mathrm{~cm}$ (J4), and $35 \times 35 \mathrm{~cm}$ (J5). The spacing resulted in plant population densities of $44.4,25.0,16.0,11.1$ and 8.1 plant $\mathrm{m}^{-2}$.

Land processing was done using a hand tractor, then the farm was divided into three groups. Distance among groups is $100 \mathrm{~cm}$ and distance among plot is $30 \mathrm{~cm}$. Observation was done by taking 4 plants sample randomly at the age $27,32,45,53,71,83$ and 100 days after planting (DAP) on observed parameters. Radiation interception was measured on above and under plant canopy by using light meter. Solar radiation data was taken daily from Karangkates Climate Station, Malang. The observation consisted of observation on dry matter production, interception efficiency and conversion efficiency. The data was analyzed using analysis of variance (F-test) at the significant level $5 \%$.

\section{RESULT AND DISCUSSION}

\section{Dry Matter Production}

The total DM production for each of the varieties and PPD variation were indicated (data not shown) in Figure 1. The DM production was slowing after reach total biomass values of 6.95 and $7.23 \mathrm{~g} \mathrm{plant}^{-1}$ on 45 DAP for both Kelinci and Kancil varieties (Figure 1a). However the crop growth rate increased substantially until harvest time for both Kelinci and Kancil varieties, respectively. The all PPD variation indicated that DM production were similar in the early growth of crops until 45 DAP (Figure 1b). The DM production in the 8.1 plant $\mathrm{m}^{-2}$ was higher than the others were, due to the high accumulation of storage in pods. The maximum DM production were reached on 100 DAP for all crops (Figure 1b). The polynomial model for predicting DM production as function of DAP, $y$ $=18.66 \mathrm{x}-14.44, \mathrm{R}^{2}=0.909$ (Kelinci), $\mathrm{y}=$ 17.98x-10.41, $\mathrm{R}^{2}=0.902$ (Kancil), $\mathrm{y}=-$ $4.542 \mathrm{x}^{2}+49.57 \mathrm{x}-33.92, \mathrm{R}^{2}=0.888$ (J1), $\mathrm{y}=$ $0.284 \mathrm{x}^{2}+17.29 \mathrm{x}-9.346, \quad \mathrm{R}^{2}=0.942(\mathrm{~J} 2), \mathrm{y}=$ $4.243 \mathrm{x}^{2}-11.61 \mathrm{x}+22.13, \mathrm{R}^{2}=0.903$ (J3), $\mathrm{y}=$ $4.218 \mathrm{x}^{2}-12.18 \mathrm{x}+25.61, \mathrm{R}^{2}=0.874(\mathrm{~J} 4)$, and $\mathrm{y}=$ $4.658 x^{2}-13.5 x+16.10, R^{2}=0.887$ (J5) (Figure 1). The polynomial model for DM production influenced plant population density and type of crops variety also had been reported the other researcher [7].
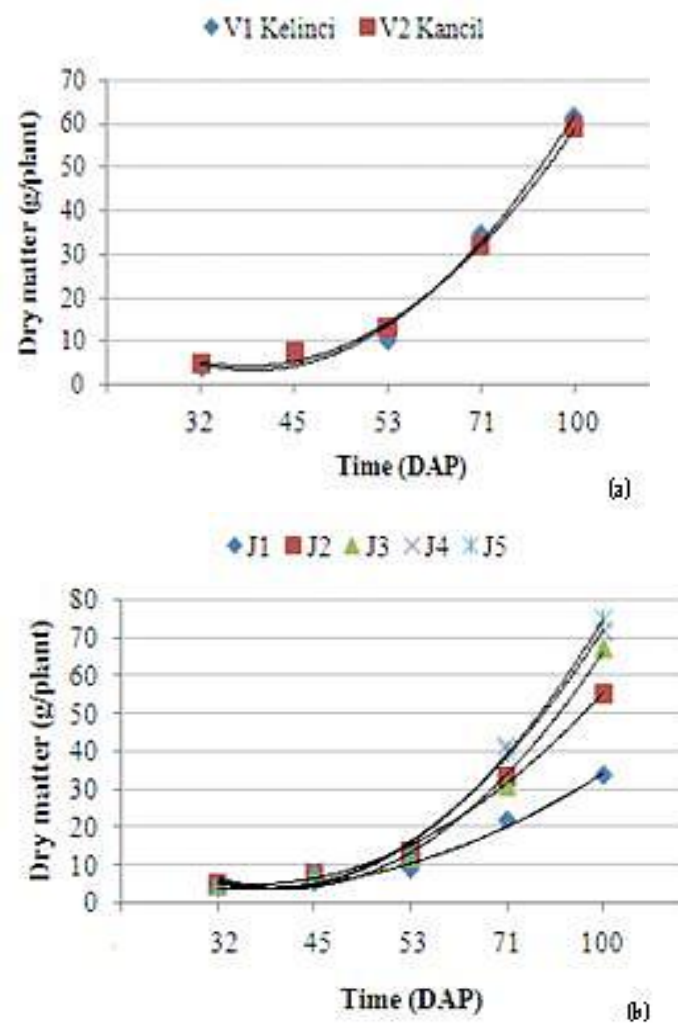

Figure 1. Dry matter production during the growing of Kelinci and Kancil variety (a) and plant population densities of 8.1 (J5), 11.1(J4), 16.0 (J3), 25.0(J2) and 44.4 plant $\mathrm{m}^{-2}$ (J1) (b).

\section{Interception Efficiency}

The Interception efficiency during the growing of Kelinci and Kancil varieties was presented on Figure 2. That was showed that the both variety have similar to IE of solar radiation in the early crops until 100 DAP, IE of solar radiation of Kancil variety $(95.68 \%)$ slightly higher than Kelinci $(95.06 \%)$. The IE value for both crops after 27 DAP decreases until age 32 DAP (10.45$15.93 \%)$, afterwards increases until age 71 DAP (95.06-95.68\%) (Figure 2a). The PPD variation was influenced at the age 32 DAP until harvest. Plant population with a high density (44.4 plant $\mathrm{m}^{-2}$ ) increased the IE of solar radiation to 98.23\% (Figure 2b). Combination between variety and plant population did not give a significant different on IE of the solar radiation. The model used to predict IE for each day was $y$ $=0.08 \mathrm{x}^{2}-0.148 \mathrm{x}+0.34$ with $\mathrm{R}^{2}=0.939$ (Kelinci), $y=0.069 x^{2}-0.136 x+0.408, R^{2}=0.977$ (Kancil), $y=0.087 x^{2}-0.116 x+0.586, R^{2}=0.929$ (J1), $y=0.080 x^{2}-0.099 x+0.434, R^{2}=0.948(J 2)$, $\mathrm{y}=0.098 \mathrm{x}^{2}-0.291 \mathrm{x}+0.472, \mathrm{R}^{2}=0.994(\mathrm{~J} 3), \mathrm{y}=$ $0.057 \mathrm{x}^{2}-0.104 \mathrm{x}+0.208, \mathrm{R}^{2}=0.948(\mathrm{~J} 4)$ and $\mathrm{y}=$ 
$0.05 \mathrm{x}^{2}-0.116 \mathrm{x}+0.194, \quad \mathrm{R}^{2}=0.964$ (J5), respectively (Figure 2). This solar radiation is required by plant to form biomass. Similar results have been reported by Collino et al. (2001) [8] that the EI value in the early of growth low and increasingly over until harvest.
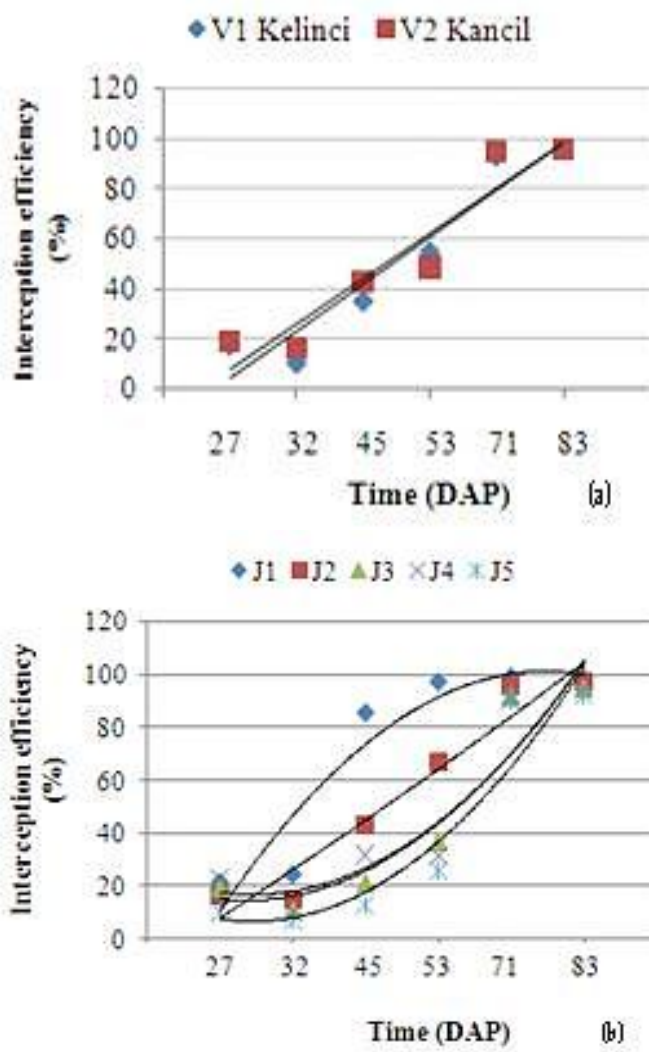

Figure 2. Interception efficiency during the growing of Kelinci and Kancil variety (a) and plant population densities of 8.1 (J5), 11.1(J4), 16.0 (J3), 25.0(J2) and 44.4 plant $\mathrm{m}^{-2}$ (J1) (b).

\section{Conversion Efficiency of Radiation Energy}

The CE of radiation energy value is shown in Figure 3. The CE value during early crop growth until harvest (100 DAP) were indicated significantly different between crops Kelinci and Kancil with values of $1.52 \%$ and $1.41 \%$ (Figure 3a). Various values have been reported for CE in crops ranging from $0.73 \%$ to $2 \%$ [9][10]. Plant population that progressively high density (44.4 plant $\mathrm{m}^{-2}$ ) increased CE values (Figure $3 \mathrm{~b}$ ). The model equation predicted that $\mathrm{CE}$ was highly correlated, $\mathrm{y}=4.948 \mathrm{x}^{2}-15.40 \mathrm{x}+15.28, \mathrm{R}^{2}=$ 0.990 (Kelinci), $y=4.447 x^{2}-13.36 x+14.39, R^{2}=$ 0.997 (Kancil), $y=2.175 x^{2}-5.440 x+6.988, R^{2}=$ $0.992(J 1), y=3.770 \mathrm{x}^{2}-10.10 \mathrm{x}+11.46, \mathrm{R}^{2}=0.995$ (J2), $y=5.792 x^{2}-19.86 x+20.30, R^{2}=0.990(J 3)$, $\mathrm{y}=5.597 \mathrm{x}^{2}-16.89 \mathrm{x}+16.45, \mathrm{R}^{2}=0.990$ (J4) and $\mathrm{y}$ $=6.153 \mathrm{x}^{2}-19.62 \mathrm{x}+18.98, \mathrm{R}^{2}=0.993(\mathrm{~J} 5)$ (Figure
3). Combination variety and plant population density in the early growth indicated a significant different on CE Value. The CE value in the early about $0.14-0.63 \%$ then gradual increased until harvest $0.83-2.08 \%$. The lower CE of peanut may be partially explained because in peanut the reserves accumulated in the base of leaves must be retranslocated to the pods. Process has an energetic cost in remobilization, transport and reallocation of the biochemical compounds as growth may have greater metabolic cost in the early stages of leaves production with greater protein oil content than that in the storage pods produced later [11]. Then, CE value for peanut are lower than for many common grain crops, because peanut pod production requires more energy than production of vegetative organs have reported by [12][13].

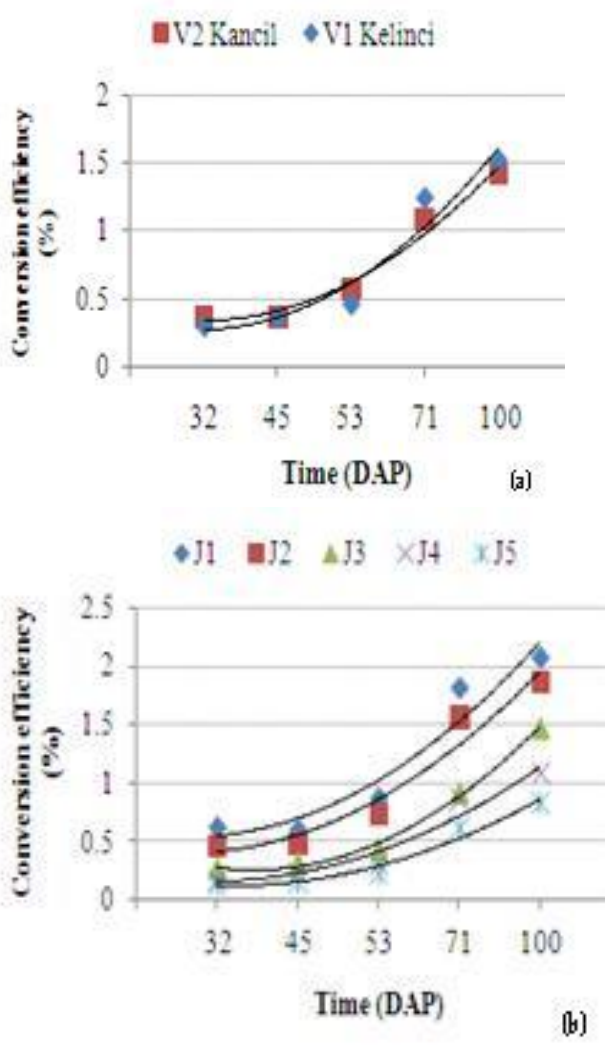

Figure 3. Conversion efficiency during the growing of Kelinci and Kancil variety (a) and plant population densities of 8.1 (J5), 11.1(J4), 16.0 (J3), 25.0(J2) and 44.4 plant $\mathrm{m}^{-2}$ (J1) (b).

\section{CONCLUSION}

The DM production from high PPD increased gradually to the lower PPD in all varieties. Interception efficiency increased for all varieties from early sowing. A plant density of $25.0 \mathrm{~m}^{-2}$ and 44.4 plants $\mathrm{m}^{-2}$ intercepted more radiation over 11.1 or 16.0 plants $\mathrm{m}^{-2}$. Conversion efficiency of radiation energy on 
Kelinci variety $(1.52 \%)$ had a higher value than that in Kancil variety $(1.41 \%)$.

\section{ACKNOWLEDGMENTS}

The first author would like to thank to Rector of the University of Tidar, Magelang, for financial support to conduct this study at Brawijaya University. We thank to head of Indonesian Legume and Tuber Crops Research Institute, Malang, East Java, Indonesia for generously permitting this Research at his research farm.

\section{REFERENCES}

1. Vargas L A, M N Andersen, C R Jensen and U Jǿrgensen (2002) Estimation of leaf area index, light interception and biomass accumulation of Miscanthussinensis 'Goliath' from radiation measurements. Biomass and Bioenergy. 22: 1-14.

2. Rochette P, R I Desjardins, E Pattey and R Lessard (1991) Crop net carbon dioxide exchange rate and radiation use efficiency in soybean. Agron J. 87: 22-28.

3. Thiébeau P, N Beaudoin, E Justes, JM Allirand and G Lemaire (2011) Radiation use efficiency and shoot:root dry matter partitioning in seedling growths and regrowth crops of lucerne (Medicago sativa L.) after spring and autumn sowings. European Journal of Agronomy. 35(4): 255-268.

4. Sinclair T R and R S Muchow (1999) Radiation use efficiency. Advances In Agronomy. 65: 215 265.

5. Purcell L C, R A Ball, J D Reaper and E D Vories (2002) Radiation use efficiency and biomass production in soybean at different plant population densities. Crop Sci. 42: 172-177.

6. Kiniry JR, C E Simpson, A M Schubert and J D Reed (2005) Peanut leaf area index, light interception, radiation use efficiency and harvest index at three sites in Texas. Field Crops Res. 91: 297-306.

7. Tarimo A J P and F P Blamey (1999) Effect of population density and cultivar on growth, yield and yield components in groundnut (Arachishypogaea L.). S Afr J Plant Soil. 6(2): 7478.

8. Collino D J, J L Dardanelli, R Sereno and R W Racca (2001) Physiological responses of argentine peanut varieties to water stress: Light interception, radiation use efficiency and partitioning of assimilates. Field Crops Research. 70: 177-184.

9. Gibbon D, R Holliday, F Mattei and G Luppi (1970) Crop production potential and energy conversion efficiency in different environments. Exp Agric. 6: 197-204.
10. Coulson C L (1985) Radiant energy conversion in three cultivars of Phaseolus vulgaris. Agric Forest Meteorol. 35: 21-29.

11. Penning de Vries F W T, A H M Brunsting and A H van Laar (1974) Product requeriments and efficiency of biosynthesis, a quantitative approach. J Theor Biol. 45: 339-377.

12. Kiniry J R, C A Jones, J C O’Toole, R Blanchet, M Cabelguenne and D A Spanel (1989) Radiation use efficiency in biomass accumulation prior to grain-filling for five grain-crop species. Field Crops Res. 20: 51-64.

13. Yeates S J, G A Constable and T McCumstie (2010) Irrigated cotton in the tropical dry season. II: Biomass accumulation, partitioning and RUE. Field Crops Research. 116(3): 290-299. 